\title{
Pengaruh Budaya Organisasi dan Lingkungan Kerja Terhadap Kinerja Karyawan PT. Harap Panjang Pekanbaru
}

\author{
LAMIN \\ Sekolah Tinggi Ilmu Ekonomi Riau (STIER) \\ Jln. HR. Subrantas 57 Panam Pekanbaru 28293 Telp. (0761) 63237 \\ E-mail: akbar_stier@yahoo.com
}

\begin{abstract}
Population in this research is all employees at PT Harap Panjang Pekanbaru. And the 35 employees were sampled. Based on the result of research analysis found the test result on organizational culture variable (X1) on performance $(\mathrm{Y})$ can be seen that t-count bigger than t-table $(2,564>1,693)$ with significant level 0,01 . Thus it can be concluded that the organizational culture variable (X1) has a positive and significant effect on employee performance (Y). And work environment variable (X2) to performance (Y) can be seen that tcount bigger than t-table $(2,707>1,693)$ with significant level 0,01 . Thus it can be concluded that the work environment variable (X2) has a positive and significant effect on employee performance $(\mathrm{Y})$. Results of multiple linear regression shows $\mathrm{Y}=\mathrm{a}+\mathrm{bX} 1+\mathrm{bX} 2$ ie: $\mathrm{Y}=$ $4,042+0,438 \mathrm{X}+0,433 \mathrm{X}$ From the regression equation it is concluded that the regression coefficient of bx is positive. This shows the organizational culture and the work environment if enhanced persamaanya will lead to an increase also on the performance of employees of PT. Harap Panjang Pekanbaru. R Square result of 0,596 (59,6\%) explained that employees performance of PT Harap Panjang pekanbaru influenced by organizational culture and work environmentequalto59,6\%
\end{abstract}

Keywords: Organizational Culture, Work Environment, Employee Performance

Kinerja karyawan merupakan salah satu faktor penting dalam kemajuan suatu perusahaan. Kinerja karyawan menjadi sangat penting karena penurunan kinerja baik individu maupun kelompok dalam suatu perusahaan dapat memberi dampak yang berarti dalam suatu perusahaan. Sehingga dalam hal ini seorang manajer memiliki tugas yang cukup berat dimana dia harus selalu berusaha meningkatkan kinerjanya dan memberi motivasi bagi bawahannya agar dapat meningkatkan kinerjanya untuk mencapai tujuan perusahaan.

Karyawan adalah asset penting bagiperusahaan (organisasi).Keberadaan asset ini adalah fakta bila SDMmerupakan bagian integral dari organisasi, sehingga segala masalah yangterkait dengan SDM di organisasi harus dipecahkan dengan baik danbenar.Douglas (1996) menjelaskan bahwa perusahaan membutuhkankaryawan yang mampu bekerja lebih baik dan lebih cepat, sehinggadiperlukan karyawan yang mempunyai kinerja (Job Performance) yangtinggi. Berbagai cara ditempuh untuk meningkatkan kinerja pegawaimisalnya melalui pendidikan dan pelatihan, pemberian kompensasi danmotivasi serta menciptakan lingkungan kerja yang baik.

Salah satu perusahaan yang bergerak dibidang konstruksi adalah PT Harap Panjang Cabang Pekanbaru. PT. Harap Panjang merupakan salah satu perusahaan yang bergerak di bidang jasa kontraktor dengan bidang pekerjaan jalan dan jembatan. Seperti halnya perusahaan swasta lain, perusahaan ini memiliki sertifikat ISO 9001 : 2000 dari TUV CERT yang mengutamakan kualitas dan kuantitas produksi yang akan dipasarkan, sehingga perusahaan mendapatkan laba yang continous pada proyek-proyek dinas pekerjaan umum atau swasta yang terdapat di Propinsi Riau.

Adapun pengertian beton aspal adalah jenis perkerasan jalan yang terdiri dari campuran aggregate dan aspal, dengan atau tanpa bahan tambahan. Material-material pembentuk beton aspal 
dicampur di instalasi pencampur pada suhu tertentu, kemudian diangkut ke lokasi, dihamparkan dan di padatkan. Suhu pencampuran ditentukan berdasarkan jenis aspal yang akan digunakan. Jika digunakan semen aspal, maka suhu pencampuran umumnya antara $145^{\circ}-155^{\circ} \mathrm{C}$, sehingga disebut beton aspal campuran panas. Campuran ini dikenal dengan nama hotmix. Beton aspal yang menggunakan aspal cair dapat dicampur pada suhu ruang sehingga dinamakan coldmix.

Keberhasilan suatu organisasi sangat erat kaitannya dengan kualitas kinerja para anggotanya, sehingga organisasi dituntut untuk selalu mengembangkan dan meningkatkan kinerja dari para anggotanya. Berdasarkan tabel diatas, dapat dijelaskan bahwa target kerja karyawan yang bekerja pada PT.Harap Panjang Cabang Pekanbaru, mengalami fluktuasi atau naik turunnya target kerja yang dicapai perusahaan, hal tersebut dapat dilihat pada tahun 2011 mencapai target sedangkan tahun 2012 dan 2013 mengalami penurunan dan pada tahun 2014 dan 2015 mengalami peningkatan, yaitu sebesar diatas $100 \%$, namun pada tahun terakhir yaitu tahun 2016 terjadi penurunan kembali. Terjadinnya penurunan target kerja pada karyawan dipengaruhi oleh beberapa faktor, diantaranya adalah faktor lingkungan kerja dan budaya organisasi yang ada pada perusahaan.

Kinerja berarti hasil kerja yang dapat di tampilkan atau penampilan kerja seorang karyawan, dengan demikian kinerja karyawan dapat diukur dari hasil kerja, hasil tugas, atau hasil kegiatan kurun waktu tertentu. Kinerja karyawan yang tinggi akan mendukung produktivitas organisasi, sehigga sudah seharusnya pimpinan organisasi senantiasa memperhatikan peningkatan kinerja anggotanya demi kemajuan organisasi. Peningkatan kinerja para anggota juga erat kaitannya dengan cara bagaimana organisasi mengembangkan budaya organisasi yang ada.
Budaya merupakansuatu sistem makna bersama yang dianut oleh anggota - anggota organisasi yangmembedakan organisasi itu dari organisasi - organisasi lain Pemahaman tentangbudaya organisasi perlu ditanamkan sejak dini kepada karyawan. Bila pada waktupermulaan masuk kerja, mereka masuk keperusahaan dengan berbagai karakteristikdan harapan yang berbeda - beda, maka melalui training, orientasi dan penyesuaiandiri, karyawan akan menyerap budaya perusahaan yang kemudian akan berkembangmenjadi budaya kelompok, dan akhirnya diserap sebagai budaya pribadi. Bila prosesinternalisasi budaya perusahaan menjadi budaya pribadi telah berhasil, makakaryawan akan merasa identik dengan perusahaannya, merasa menyatu dan tidak adahalangan untuk mencapai kinerja yang optimal. Ini adalah kondisi yang salingmenguntungkan, baik bagi perusahaan maupun karyawan.

Budaya organisasi yang dibangun oleh PT. Harap Panjang Cabang Pekanbaru selama ini adalah kewajiban lembur jika ada pekerjaan mendadak, semua karyawan wajib mengikuti lembur jika diperintahkan oleh pimpinan. Kurangnya rasa mematuhi aturan kerja, banyak karywan yang sering tidak masuk tanpa alasan yang jelas. Dan juga iklim kerja yang kurang mendukung yaitu kurangnya rasa kebersamaan diantara karyawan.

Dan juga berdasarkan pengamatan dan wawancara yang dilakukan peneliti, diperoleh bahwa budaya yang terjadi di PT Harap Panjang adalah: Kondisi lingkungan yang kurang kondusif; Banyak peralatan yang tidak disertai dengan sistem keamanan; Banyak ruangan yang masih terasa panas dan pengap karena kurangnya sirkulasi udara; Kurangnya rasa kebersamaan diantara karyawan.

Lingkungan kerja yang baik akan berdampak pada hasil kerja yang akan dicapai oleh karyawan. Untuk mencapai tujuan dari organisasi, diperlukan lingkungan kerja yang baik serta sumber 
daya manusia yang berkomitmen tinggi dan pengawasan oleh pimpinan yang dapat mempengaruhi kinerja dan tingkat prestasi suatu organisasi.

Payaman (2011:2) mengartikan kinerja sebagai pencapaian hasil atas pelaksanaan tugas tertentu. Dijelaskan juga bahwa kinerja pegawai adalah tingkat pencapaian hasil kerja pegawai dalam rangka mewujudkan tujuan organisasi. Penjelasan ini sejalan dengan yang dikemukakan Siswanto (2010:231) bahwa kinerja adalah kemampuan dalam melaksanakan tugasnya yang didasarkan kecakapan, usaha dan kesempatan. Artinya, kinerja sangat erat hubungannya dengan kemampuan seseorang dalam melaksanakan tugas.

Kinerja berasal dari kata job performance atau actual performence (prestasi kerja atau prestasi sesungguhnya yang dicapai oleh seseorang). Pengertian kinerja (prestasi kerja) adalah hasil kerja secara kualitas dan kuantitas yang dicapai oleh seseorang pegawai dalam melaksanakan tugasnya sesuai dengan tanggung jawab yang diberikan kepadanya (Mangkunegara, 2011:67). Kinerja (performance) adalah hasil pekerjaan yang dicapai seesorang berdasarkan persayaratan - persyaratan pekerjaan (job requirement). Suatu pekerjaan mempunyai persyaratan tertentu untuk dapat dilakukan dalam mencapai tujuan yang disebut juga sebagai standar pekerjaan (job standard) (Bangun, 2012:231).

Menurut Dale Timple dalam Mangkunegara (2011:15), faktor- faktor kinerja terdiri dari faktor internal dan faktor eksternal. Faktor internal (disposisional) yaitu faktor yang dihubungkan dengan sifat-sifat seseorang. Misalnya, kinerja seseorang baik disebabkan karena mempunyai kemampuan tinggi dan seseorang itu tipe pekerja keras, sedangkan seseorang mempunyai kinerja jelek disebabkan orang tersebut mempunyai kemampuan rendah dan orng tersebut tidak memiliki upaya-upaya untuk memperbaiki kemampuannya. Faktor eksternal yaitu faktor-faktor yang mempengaruhi kinerja seseorang yang bersal dari lingkungan. Seperti perilaku, sikap, dan tindakantindakan rekan kerja, bawahan atau pemimpin, fasilitas kerja, kepuasan kerja dan iklim atau budaya organisasi.

Siswanto (2010:234) menjelaskan bahwa faktor-faktor yang mempengaruhi kinerja pegawai adalah pekerjaan yang menarik, upah yang baik, kemanan dan perlindungan dalam pekerjaan, penghayatan atas maksud dan makna pekerjaan, lingkungan atau suasana kerja yang baik, promosi dan pengembangan diri, merasa terlibat dalam kegiatan organisasi, kepemimpinan, dan disiplin kerja yang keras.

Payaman (2011:10) menjelaskan bahwa kinerja setiap orang dipengaruhi oleh banyak faktor yang dapat dikelompokkan pada 3 (tiga) kelompok, yaitu: (1) kompetensi individu seperti kemampuan dan keterampilan kerja melakukan kerja; (2) dukungan organisasi seperti ketersediaan sarana dan prasarana kerja, kepuasan kerja, kompensasi dan kenyamanan lingkungan kerja; dan (3) dukungan manajemen seperti kepemimpinan, dan lingkungan kerja. Rivai (2004:309) menambahkan bahwa kegiatan pelatihan adalah salah satu faktor yang dapat berpengaruh terhadap kinerja pegawai.

Menurut Mathis dan Jockson (2006:378) menjelaskan bahwa indikator kinerja pegawai adalah ukuran kauntitatif dan kualitatif yang mengambarkan tingkat pencapaian sasaran dan tujuan kerja pegawai. Dijelaskan juga bahwa beberapa indikator yang dapat dipakai untuk mengukur kinerja pegawai adalah kualitas pekerjaan, kuantitas, ketepatan waktu, kehadiran dan kerjasama, dengan penjelasan sebagai berikut : Kualitas, Menyangkut kesesuaian hasil dengan yang diinginkan atau direncanakan. Kuantitas, Yaitu jumlah yang dihasilkan baik dalam nilai uang, jumlah unit atau jumlah lingkaram aktifitas atau jumlah kegiatan. Ketepatan Waktu, Sesuai

p.ISSN: $2407-800 X \quad$ e.ISSN: 2541-4356 
dengan standar yang ditetapkan organisasi pelaksanaan kerja dapat disesuaikan dalam waktu yang ditentukan. Kehadiran, Jumlah kegiatan yang dihadiri pegawai dalam masa kerja organisasi. Kerjasama, Menyangkut peningkatan harga diri, hubungan baik dan kerjasama antara teman kerja, maupun kepada bawahan dan atasan.

Menurut Robbins (2007:12) : "Kebudayaan merupakan inti dari apa yang penting dalam organisasi, seperti aktivitas memberi perintah, dan larangan serta menggambarkan sesuatu yang dilakukan dan tidak dilakukan yang mengatur perilaku anggota". Robbins (2007:14) : "Budaya merupakan berbagai interaksi dari ciri-ciri kebiasaan yang mempengaruhi kelompok-kelompok orang dalam lingkungannya". Jadi budaya mengandung apa yang boleh dilakukan atau tidak boleh dilakukan sehingga dapat dikatakan sebagai suatu pedoman yang dipakai untuk menjalankan aktivitas organisasi.

Pada dasarnya budaya organisasi dalam perusahaan merupakan alat untuk mempersatukan setiap individu yang melakukan aktivitas secara bersama-sama. Lebih lanjut Robbins (2007:22), mengemukakan bahwa "Budaya organisasi adalah perekat sosial yang mengikat anggota organisasi”. Nampaknya agar suatu karakteristik atas kepribadian yang berbeda-beda antara orang yang satu dengan orang yang lain dapat disatukan dalam suatu kekuatan organisasi maka perlu adanya perekat sosial.

$$
\text { Menurut Robbins }
$$

"Budaya organisasi diartikan sebagai sistem makna yang dianut oleh anggotaanggota yang membedakan suatu organisasi dengan organisasi yang lain". Dalam bukunya yang lain Robbins (2007:479) menyatakan "Budaya organisasi berupa nilai-nilai dominan yang didukung oleh anggota organisasi, atau falsafah yang menuntun kebijakan organisasi terhadap pegawai dan pelanggan, atau bisa juga diartikan sebagai cara pekerjaan dilakukan ditempat itu, atau asumsi dan kepercayaan dasar yang terdapat diantara anggota oganisasi”. Secara singkat Budaya organisasi berarti suatu sistem pengertian yang diterima secara bersama.

Budaya organisasi merupakan falsafah, ideologi, nilai-nilai, anggapan, keyakinan, harapan, sikap dan normanorma yang dimiliki secara bersama serta mengikat dalam suatu komunitas tertentu (Robbins, 2007:721).

Budaya organisasi merupakan bentuk keyakinan, nilai, cara yang bisa dipelajari untuk mengatasi dan hidup dalam organisasi, budaya organisasi itu cenderung untuk diwujudkan oleh anggota organisasi (Brown, 1998: 34). Robbins, (2007: 525) menjelaskan bahwa budaya organisasi itu merupakan suatu system nilai yang dipegang dan dilakukan oleh anggota organisasi, sehingga hal yang sedemikian tersebut bisa membedakan organisasi tersebut dengan organisasi lainnya. Sistem nilai tersebut dibangun oleh 7 karakteristik sebagai sari (essence) dari budaya organisasi, 7 karakteristik

Menurut Kreitner (2014:62) budaya organisasi dibentuk oleh 4 komponen kunci, antara lain : Nilai-nilai pendiri. Lingkungan industri dan bisnis. Kebudayaan nasional. Visi dan sikap pemimpin senior.

Secara spesifik budaya dalam organisasi akan dipengaruhi oleh kerja sama tim, kepemimpinan, karakteristik organisasi dan proses administrasi yang berlaku. Mengapa budaya organisasi penting karena merupakan kebiasan-kebiasaan yang terjadi dalam hirarki organisasi yang mewakili norma-norma perilaku yang diikuti oleh anggota organisasi. Budaya yang produktif adalah budaya yang dapat menjadikan organisasi menjadi kuat dan tujuan organisasi dapat terakomodasi (Sinungan, 2003:48).

Menurut Robbins (2007 : 294), fungsi atau manfaat dari budaya organisasi yang baik adalah sebagai berikut : Budaya mampu menciptakan pembedaan yang jelas antara satu organisasi dan yang lain. Budaya dapat membawa suatu rasa identitas bagi

p.ISSN: 2407-800X e.ISSN: 2541-4356 
anggota-anggota organisasi. Budaya mempermudah timbulnya komitmen pada sesuatu yang lebih luas daripada kepentingan diri individual seseorang. Budaya merupakan perekat sosial yang membantu mempersatukan organisasi itu dengan memberikan standar-standar yang tepat untuk dilakukan oleh karyawan. Budaya sebagai mekanisme pembuat makna dan kendali yang memandu dan membentuk sikap serta perilaku karyawan.

Menurut Luthans (2011:72) Budaya organisasi memiliki sejumlah indikator yang penting, diantaranya adalah : Keteraturan Perilaku (Observed behavioral regularities) Karakter ini terlihat pada interaksi antara satu dg yang lain, kesamaan tingkah laku, pemakaian bahasa, dan lain-lain. Norma ( Norms )

Yaitu standar pedoman yang ada, misalnya seberapa banyak pekerjaan yang wajib di selesaikan. Nilai Utama (Dominant Values). Nilai-nilai utama organisasi yang menganjurkan dan mengharapkan anggota untuk melakukan sesuatu yang penting, contohnya efisiensi, dan hasil yang berkualitas. Filosofi (philosopy). Adalah kebijakan yang ditetapkan tentang bagaimana karyawan dan pelanggan harus diperlakukan. Aturan (Rules). Panduan yang ketat yang harus diikuti oleh pegawai baru untuk diterima bergaul di lingkungan organisasi. Iklim organisasi (Organization climate). Yaitu keseluruhan yang berhubungan dengan tata ruang, dan cara berinteraksi dengan pegawai lain .

Menurut Sedarmayanti (2011:26) mengatakan bahwa lingkungan kerja sebagai keseluruhan alat perkakas dan bahan yang dihadapi, lingkungan sekitarnya dimana seseorang bekerja,. Metode kerjanya, serta pengaturan kerjanya baik sebagai perseorangan mauun sebagai kelompok.

Menurut Sihombing (2008:175)

Lingkungan Kerja adalah faktor-faktor di luar manusia baik fisik maupun non fisik dalam suatu organisasi tersebut. Faktor fisik ini mencakup peralatan kerja, suhu tempat kerja, kesesakan dan kepadatan, kebisingan, luas ruang kerja sedangkan non fisik mencakup hubungan kerja yang terbentuk di instansi antara atasan dan bawahan serta antara sesama karyawan. Lingkungan kerja yang mendukung motivasi kerja akan menimbulkan kepuasan kerja bagi pekerja dalam suatu organisasi. Indikator lingkungan kerja adalah (1) fasilitas kerja, (2) gaji dan tunjangan, (3) hubungan kerja .

Kondisi kerja yang baik serta nyaman akan dapat tercipta dengan adanya penyusunan organisasi secara baik dan benar. Terciptanya suasana kerja sangat dipengaruhi oleh struktur organisasi yang ada di dalam organisasi. Sedarmayanti (2009:21) mengatakan bahwa lingkungan kerja adalah keseluruhan alat perkakas dan bahan yang dihadapi, lingkungan sekitarnya di mana seseorang bekerja, metode kerjanya, serta pengaturan kerjanya baik sebagai perseorangan maupun kelompok.

Sedarmayanti menyatakan bahwa secara garis besar, jenis lingkungan kerja terbagi menjadi dua (2) yakni:Lingkungan kerja fisik.Lingkungan kerja fisik adalah semua keadaan berbentuk fisik yang terdapat di sekitar tempat kerja yang dapat mempengaruhi karyawan baik secara langsung maupun tidak langsung. Lingkungan kerja fisik dapat dibagi dalam dua kategori, yakni: Lingkungan yang langsung berhubungan dengan karyawan (seperti: komputer, UPS, printer, meja, kursi dan sebagainya). Lingkungan perantara atau lingkungan umum dapat juga disebut lingkungan kerja yang mempengaruhi kondisi manusia, misalnya temperature, kelembapan, sirkulasi udara, pencahayaan, kebisingan, getaran mekanis, tempat parker, bau tidak sedap, serta warna.

Lingkungan kerja non fisik. Menurut Sedarmayanti (2009:31) mendefinisikan lingkungan kerja non fisik adalah semua keadaan yang berkaitan dengan hubungan kerja, baik hubungan

p.ISSN: $2407-800 X \quad$ e.ISSN: 2541-4356 
dengan atasan maupun hubungan sesame rekan kerja, ataupun hubungan dengan bawahan.

Indikator-indikator lingkungan kerja menurut Sedarmayanti (2009:46) adalah sebagai berikut : Penerangan, Dengan penerangan yang baik tentunya akan memudahkan para pekerja dalam melakukan aktivitas. Suhu udara, Berbicara mengenai suhu udara ada 2 hal yang sangat penting yaitu kelembaban udara dan juga sirkulasi udara.dengan udara yang segar dan selalu berganti tentunya akan membuat karyawan nyaman dalam bekerja. Kebersihan, Kebersihan dapat menggangu konsentrasi dalam bekerja,sehingga perlu adanya penjagaan kebersihan bersama yang bisa membuat tempat bekerja lebih nyaman. Penggunaan warna, Warna ruangan mempunyai pengaruh terhadap gairah dan semangat kerja para pegawai dan pekerja di dalam ruangan tersebut.Keamanan kerja, Keamanan penggunaan ruangan dan peralatan sangat menentukan semangat kerja karyawan. Hubungan anatar karyawan, saling menjaga hubungan baik dan juga kerja sama antar para karyawan. Hubungan baik dan kerjasama antar karyawan dan juga pimpinan.

\section{METODE}

Lokasi penelitian yaitu : PT. Harap Panjang Cabang Pekanbaru yang terletak di jalan Tuanku Tambusai No. 389 Pekanbaru dengan menggunakan data : Data Primer, Yaitu data yang dikumpulkan secara langsung dari hasil wawancara atau interview dengan responden serta data-data lainnya yang diperoleh dari objek penelitian. Adapun datanya yaitu pertanyaan-pertanyaan yang diajukan kepada para karyawan yang menyangkut indikator-indikator yang ada divariabel penelitian. Data Sekunder, yaitu data yang telah diolah dan telah tersaji serta telah ter dokumentasi.

Dalam penelitian ini populasinya adalah semua karyawan bagian Administrasi di PT. Harap Panjang Cabang Pekanbaru yaitu sebanyak 35 orang responden. Dan dalam penelitian ini menggunakan sampel jenuh, yaitu populasi dijadikan sampel, yaitu sebesar 35 orang.

Teknik yang digunakan penulis dalam pengumpulan data penelitian ini adalah: Interview (Wawancara) Merupakan prosedur pengumpulan data dengan mengajukan pertanyaan-pertanyaan kepada pemimpin perusahaan serta karyawan yang berhubungan dengan masalah yang penulis teliti. Questioner, adalah suatu cara pengumpulan data melalui pertanyaan yang telah penulis siapkan yang ditujukan kepada responden yang akan dijadikan sampel. Dengan mencatat data yang tersedia yang berhubungan dengan permasalahan penelitian yang ada.

Dalam menganlisis data yang diperoleh, penulis menggunakan metode kuantitatif dengan analisis regresi berganda, yaitu suatu cara yang dapat menjelaskan hasil penelitian yang ada dengan menggunakan persamaan rumus matematis dan menghubungkannya dengan teori yang ada, kemudian ditarik kesimpulan.Regresi linear berganda digunakan oleh peneliti, bila peneliti bermaksud meramalkan bagaimana keadaan (naik turunnya) variabel dependen (kriterium), bila dua atau lebih variabel indpenden sebagai faktor prediktor dimanipulasi (dinaik turunkan nilainya). Jadi analisis regresi berganda akan dilakukan bila jumlah variabel independennya minimal dua (sugiyono,(2010:243)):

$\mathrm{Y}=\mathrm{a}+\mathrm{b} 1 \mathrm{x} 1+\mathrm{b} 2 \mathrm{x} 2$

Keterangan:

$\mathrm{Y}=$ kinerja karyawan

$b=$ koefisien Regresi

$\mathrm{a}=$ konstanta

$\mathrm{X}=$ variabel bebas

\section{HASIL}

Dari data diatas jika nilai t hitung dibandingkan dengan $\mathrm{t}$ tabel hasilnya adalah 2,564>1,693dan nilai siginifikansi sebesar $0,01<0,05$ artinya secara parsial budaya organisasi berpengaruh signifikan terhadap kinerja karyawan.

p.ISSN: 2407-800X e.ISSN: 2541-4356 
Dari data diatas jika nilai $\mathrm{t}$ hitung dibandingkan dengan t tabel hasilnya adalah $2,707>1,693$ dan nilai siginifikansi sebesar $0,01<0,05$ artinya secara parsial lingkungan kerja berpengaruh signifikan terhadap kinerja karyawan. Dari tabel ANOVA diperoleh nilai $\mathrm{F}$ sebesar 23,558 dengan nilai probabilitas (Sig.) $=0,000$, karena nilai sig $<0,05$ maka hasilnya adalah budaya organisasi dan lingkungan kerja secara bersama-sama berpengaruh signifikan terhadap kinerja karyawan PT. Harap Panjang Pekanbaru.

Pada penelilitan ini nilai Adjusted R Square dapat nilai Adjusted R Square sebesar 0,596 Artinya adalah bahwa sumbangan pengaruh budaya organisasi dan lingkungan kerja terhadap kinerja karyawan PT Harap Panjang Pekanbaru adalah sebesar 59,6\%.

\section{PEMBAHASAN}

Dari tabel ANOVA diperoleh nilai $F$ sebesar 23,558 dengan nilai probabilitas (Sig.) $=0,000$, karena nilai sig $<0,05$ maka hasilnya adalah budaya organisasi dan lingkungan kerja secara bersama-sama berpengaruh signifikan terhadap kinerja karyawan PT. Harap Panjang Pekanbaru. Dan sumbangan besaran pengaruh budaya organisasi dan lingkungan kerja terhadap kinerja karyawan sebesar 59,6 \%. Dan hasil penelitian ini sejalan dengan teori yang dikemukakan oleh Payaman (2011:10) menjelaskan bahwa kinerja setiap orang dipengaruhi oleh banyak faktor yang dapat dikelompokkan pada 3 (tiga) kelompok, yaitu: (1) kompetensi individu seperti kemampuan dan keterampilan kerja melakukan kerja; (2) dukungan organisasi seperti ketersediaan sarana dan prasarana kerja, kepuasan kerja, kompensasi dan kenyamanan suasana kerja; dan (3) dukungan manajemen seperti kepemimpinan, dan lingkungan kerja.

\section{SIMPULAN}

Dari beberapa uraian perbab dan hasil pembahasan penelitian maka penulis membuat kesimpulan sebagai berikut : Dari hasil olah data SPSS diperoleh nilai t hitung dibandingkan dengan t tabel hasilnya adalah
$2,564>1,693$ dan nilai siginifikansi sebesar $0,01<0,05$ artinya secara parsial budaya organisasi berpengaruh signifikan terhadap kinerja karyawan. Dan dari nilai $t$ hitung dibandingkan dengan $t$ tabel hasilnya adalah 2,707>1,693 dan nilai siginifikansi sebesar $0,01<0,05$ artinya secara parsial lingkungan kerja berpengaruh signifikan terhadap kinerja karyawan.Dari tabel ANOVA diperoleh nilai $F$ sebesar 23,558 dengan nilai probabilitas (Sig.) $=$ 0,000 , karena nilai sig $<0,05$ maka hasilnya adalah budaya organisasi dan lingkungan kerja secara bersama-sama berpengaruh signifikan terhadap kinerja karyawan PT. Harap Panjang Pekanbaru. Dan sumbangan besaran pengaruh budaya organisasi dan lingkungan kerja terhadap kinerja karyawan sebesar 59,6 \%. Dari Persamaan diatas nilai constant a sebesar 4,042 yang artinya pada saat budaya organisasi dan lingkungan kerja tidak ada atau nol, maka kinerja karyawan PT Harap Panjang tetap sebesar 4,042 satuan. Sedangkan pengaruh budaya organisasi dan lingkungan kerja adalah Positif, artinya setiap peningkatan budaya organisasi dan lingkungan kerja satu satuan akan diikuti peningkatan kinerja karyawan PT. Harap Panjang Pekanbaru satua satuan. 


\section{DAFTAR RUJUKAN}

Bangun, Wilson, 2012, Manajemen Sumber Daya Manusia, Jakarta, Erlangga.

Fred Luthans 2011. Perilaku Organisasi. Andi . Yogyakarta

Mangkunegara, Anwar Prabu. 2011. Manajemen Sumber Daya Manusia Perusahaan, Bandung, Rosdakarya.

Mathis, R.L dan Jackson.2006, Manajemen Sumber Daya Manusia. Salemba Empat. Jakarta.

Payaman Simanjuntak.2011 Manajemen dan Evaluasi Kinerja.Jakarta: Lembaga Penerbit Fakultas Ekonomi Universitas Indonesia, 2011

Rivai, Veithzal. 2004 Manajemen Sumber Daya Manusia untuk Perusahaan.PT. Raja Grafindo Persada. Jakarta.
Robbins, S.P, 2007, Perilaku Organisasi, Edisi 10, PT. Indeks Kelompok Gramedia

Sugiyono, 2010. Metode Penelitian Administrasi. Alfabeta, Bandung.

Siswanto, 2010. Pengantar Manajemen. PT. Bumi Aksara. Jakarta.

Sihombing, S,.2008 Manajemen Sumber Daya Manusia. Jakarta, Balai Pustaka.

Sedarmayanti,. 2009.Sumber Daya Manusia dan Produktivitas Kerja. Bandung, Mandar Maju ,2011.Manajemen Sumber Daya Manusia. PT. Refika Aditama. Bandung. 